\title{
Expected Future Trends in Chinese Outward Direct Investment in Africa
}

\section{Introduction}

The Chinese investments in Africa have caught the attention of the West for several reasons: they are constantly increasing, searching for market niches and are more appealing for the host economies than the Western investments are. As the most appealing mining sectors are already almost saturated, the easiest way to expand to new markets is to invest in less attractive industries. Infrastructure, healthcare and in some countries also the mining sector are the ones where China is currently getting more and more engaged.

The aim of this article is to identify the future trends in Chinese investment flows to Africa and to depict the key industries and countries to which the Chinese attention might be devoted. This paper presents an analysis of Chinese Outward Direct Investments (ODI) in Africa and a projection of future investment flows. After identifying the countries where the Chinese ODI have noticeably risen in the past 3 years, the determinants of these investment motives were examined. The paper concludes that these investments were predominantly interconnected with natural resources, but they are not the sole determinants of Chinese ODI. China is further interested in investing in countries with vast areas of arable land and with countries which it has extensive trade relations. Based on these determinants, the future trends in Chinese ODI in Africa were identified. More to the point the Author tends to answer the following questions: which countries were the largest recipients of Chinese investments recently? To which sectors do they flow? What trends can be observed in the Chinese ODI flows to Africa?

\section{Methodology and data}

The identification of the expected future trends of Chinese investment destinations is drawn upon the statistical data on Chinese Outward Direct Investment flows to Africa in the last 3 years (2008-2010). The paper focuses on those African countries that have proceeded to the list of the 15 biggest ODI recipients of 
Chinese investments in the last 3 years (Table 1). Further,it examines the biggest investment projects in these countries in the mentioned period and the determinants of the Chinese investments in them.

The main reasons why China has been investing in Africa include: supporting the export of Chinese products and services, stabilization of the supply of its natural resources, enhancing competitiveness of Chinese firms and establishing and maintaining diplomatic relations.

The main motives that lead China to invest a broad can be simply summarized as cost minimization, expansion to new markets and enhancing firm competitiveness. The determinants that are associated with seeking cost minimization include the import of primary commodities and size of arable land. On the other hand, the determinants related to seeking new export markets and enhancing firm competitiveness are GDP, GDP per capita, rule of law, Chinese exports and Doing Business ranking.

The analysis of the investment projects is based on media news, since to our knowledge there is no available complex database of these investment projects.

Among the 15 biggest recipients of the Chinese ODI flows in 2008-2010 were several countries that have sparked the Chinese investors' interest only in the last few years. Those countries that got to the focal point in 2008 and were not there before are: Mauritius, Gabon, Tanzania, Benin, Rwanda and Sierra Leone. In 2009 new countries appeared on this list: Ethiopia, Chad, Ghana, Niger, Congo and Guinea. The countries that earned China's attention 2010andascendedto the list of the 15 biggest investors for the first time in the last few years were Angola and Zimbabwe (table 1).

Table 1. Top 15 African recipients of Chinese ODI flows in 2008-2010

\begin{tabular}{|c|l|l|l|}
\hline Rank & \multicolumn{2}{|c|}{$\mathbf{2 0 0 8}$} & \multicolumn{2}{c|}{$\mathbf{2 0 1 0}$} \\
\hline 1. & South Africa & Algeria & South Africa \\
\hline 2. & Zambia & DRC & DRC \\
\hline 3. & Nigeria & Nigeria & Niger \\
\hline 4. & Madagascar & Egypt & Algeria \\
\hline 5. & Algeria & Zambia & Nigeria \\
\hline 6. & Mauritius & Ethiopia & Kenya \\
\hline 7. & Gabon & Chad & Angola \\
\hline 8. & DRC & Ghana & Zambia \\
\hline 9. & Kenya & Madagascar & Ethiopia \\
\hline 10. & Tanzania & South Africa & Ghana \\
\hline 11. & Egypt & Niger & Egypt \\
\hline
\end{tabular}


Table 1. (cont.)

\begin{tabular}{|l|l|l|l|}
\hline 12. & Benin & Kenya & Botswana \\
\hline 13. & Botswana & Congo & Congo \\
\hline 14. & Rwanda & Guinea & Zimbabwe \\
\hline 15. & Sierra Leone & Tanzania & Madagascar \\
\hline
\end{tabular}

Source: Author; based on statistical data from MOFCOM,2011.

*Countries that have just ascended to the top 15 recipients of Chinese ODI flows are in bold.

In 2008, China invested 820 million USD in establishing the Jin Fei economic zone in Mauritius. This investment represents historically the biggest financial inflow to the country. The main objective of this investment project was to establish business contacts with the rest of southeast Africa, diversification and modernization of the Mauritian economy thanks to which the export opportunities of both countries to the global market will expand. The Jin Fei economic zone protrudes from the Chinese investments in Africa, since Mauritius is neither rich in natural resources nor abundant in a cheap work force. Furthermore, the population of only 1 million people does not represent a huge consumer market either. What makes Mauritius a special investment location in Africa is its level of democracy and transparency. Both the corruption rate of the public sector and the easiness of doing business are the most favourable on the whole continent. Its membership in various African integration groups secures the country a preferential access to both south and east African markets. The government of Mauritius, besides being fully democratic and stable, also provides foreign investors with a preferential tax treatment. The investors have to pay little or no income taxes, corporate taxes, taxes from capital profits and dividends. They are also exempt from taxes and fees on profit repatriation. Mauritius thus has the potential of becoming China's entry gate to the rest of Africa. Besides having an entry port to the rest of Africa, Chinese businessmen can also enjoy a huge variety of recreational opportunities in this island state.

The Chinese interest in Gabon has increased in 2008, when the agreement on partial financing of the construction of Grand Poubara dam was signed. The construction project was connected to the extraction of iron ore in Bélinge. In the period of 2003-2010 both the Gabonese export to China and the country's GDP have grown evenly (World Bank, 2012). The only exception was the year 2009, when the global financial crisis brought a slowdown to the economy. The correlation between the primary commodity export to China and the growth of the Chinese ODI is clearly displayed in Gabon. Wood used to be the principal Gabonese export article to China. Oil has become the main export commodity in 2006 and metals overtook the first position in 2008 (UNCTAD, 2011). However, the global financial crisis has induced a decrease in the commodity trade. The Chinese ODI flows to Gabon are statistically not correlated with other determinants. 
Chinese investments in Tanzania have continuously grown in the last 3 years. Compared to other African countries, this growth was not outstanding except for the year 2008 (World Bank, 2011). Primary commodity export to China is rather low and the natural resource deposits of Tanzania are comparably lower than those of other African countries. Moreover, between 2005-2007 a conspicuous negative correlation appeared between its primary commodity exports and ODI from China. Relevant determinants behind the 2008 investment increase were Tanzania's economic growth and Chinese exports to the country.

The increasing volume of Chinese investment flows to Benin in 2008 can be ascribed to the construction of the teaching hospital in Parakou in the value of 8 million USD. In the case of Benin, there can be no doubt about the irrelevance of natural resources for these investment activities. The long-standing main import article to China is cotton and timber. In the past 8 years, Benin was among the biggest African importers of Chinese commodities (UNCTAD, 2011). The Chinese export relations with this country have definitely played a key role in the increase of China's investments in Benin. Benin is one of those countries though, where the Chinese investments keep declining. While in 2003 and 2004 it was on the top of the list, in the last two years Benin received only a fraction of what China has invested in other African countries.

The biggest expansion of the Chinese investments in Rwanda occurred in 2008. What preceded this growth was the improvement of rule of law (World Bank, 2011) in the country after the parliamentary elections. Recently, the increase of Chinese investment flows to other African countries has resulted in Rwanda's position as an ODI recipient to become average. Despite the fact that the general volume of these investments has grown in the country, Rwanda did not maintain its position on the top of the list. There is no evidence of decreased Chinese interest in Rwanda, but last year the Chinese ODI have simply grown more intensely in other countries. The long-standing top export commodities are metals and since 2008 coffee beans (UNCTAD, 2011).

Sierra Leone is one of those countries that did not spark too much of China's interest in the last 8 years with the exception of 2008. Investments, which have shifted the country to the $15^{\text {th }}$ position in 2008 , were similar to other investment projects conducted on the rest of the continent. Prime investment projects were oriented on rice cultivation, construction of ananti-malaria centre in Freetown, two schools and a stadium. Sierra Leone has limited trade relations with China and its economic output is also exiguous.

Noticeable growth in Chinese investments in Ethiopia was recorded in 2009 when agreements on the construction of highways and two hydroelectric power stations were signed. Thanks to its fast-growing sizeable population, Ethiopia is in the focal point of interest for Chinese exporters. Second to Nigeria, it has the biggest population in Africa, thus representing a large potential consumer market. The volume of GDP that the country generate splices it in the ranking as one 
of the economically biggest countries of the continent. The income per capita, though, is in the long term one of the lowest - ranging between 300 and 351 USD in the last 3 years (World Bank, 2011). Ethiopia is the $5^{\text {th }}$ biggest country concerning the area of arable land. The determinant that proves the highest correlation with the Chinese ODI flows in Ethiopia is the import of primary commodities. China imports large quantities of leather and oil products from here (UNCTAD, 2011). Metals present only a fraction of these imports. Therefore, taking into account the country's predispositions, it can be assumed that the Chinese investment influx will be aimed at agriculture.

Chinese diplomatic relations with Chad were resumed in 2006. Since then, China has participated in all the bigger development projects in the country, such as the construction of governmental buildings, hospitals, schools, water reservoirs and oil exploration. In 2009China National Petroleum Corporation started the construction of pipelines and refineries in the southwest of the country. This investment has shifted Chad to the 15 biggest recipients of Chinese investment flows in Africa in 2009. Thanks to this project, Chad became a direct consumer of its own oil, which was previously processed abroad and re-imported back to Chad to satisfy the local demand. Since 2011, an industrial zone for petrochemical production has been built near Djarmaya. A cement factory has been constructed in the southeast of the country in Baoaré. Chad belongs to one the poorest countries in Africa, affected by a series of disasters: the majority of the country's area is covered by desert, Lake Chad is on the verge of turning into a humanitarian disaster, the country has a very poor rule of law, one of the most corrupt governments lacking transparency as well as democracy and Doing Business2011 ranks it as the worst country on the continent (World Bank, 2011). The key determinant of Chinese investment activities in this country is without any doubt oil. The Chinese government is certainly motivated by the marginalisation of Taiwan, with which Chad maintained diplomatic relationsbetween1997-2006.

The University of Ghana has opened Chinese language and culture courses in 2008. Shenzen Energy Investment Corporation invested in the construction of a hydroelectric power station Sunon Asogli in Ghana. After the presidential elections in 2008, the country's rule of law has decreased and the cooperation with China has improved. China pledged to build a new office building for the Ministry of Foreign Affairs of Ghana. In the case of Ghana, a wide range of determinants of Chinese ODI can be observed. The country has a relatively high GDP compared to others in Africa. It provides its investors with a good investment climate - ranked $8^{\text {th }}$ in Doing Business 2011 (World Bank, 2011). Ghana belongs to China's leading export destinations in Africa. In 2009 China exported its first diesel fast train unit (DMU) to Africa (UNCTAD, 2011). It imports mainly cocoa, palm oil and ores from Ghana. Since 2010 it has started to import oil as well (Ibid.). China National Oil Offshore Corporation has provided the country with financial and technical assistance in oil exploration since 2009. Primary commodities of Ghana 
are definitely one of the main drivers for Chinese investors. ZTE (Zhongxing Telecommunication Equipment Corp.) has agreed on cooperation with Ghana Telecom University. Therefore, sectorial diversification of China's ODI in Ghana can be expected in the following years.

The Chinese deputy prime minister has in 2009 identified the energetic and mining sector, trade and investment development as the main areas of cooperation with Niger. The PRC has subsequently provided Niger with a loan for uranium extraction in the SOMINA mine. The construction of an oil refinery and pipelines have started in eastern Niger. The Chinese interest in Niger's natural resources was not disrupted even by the coup d'état in February 2010, when president Mamadou Tandjawas overthrown. The cooperation continues and the military junta maintains friendly relations with China. China became an alternative to the longstanding French influence, which has led the country to the bottom of human development. Niger's human development index is the second lowest in the world (Ibid.). Niger has a large area of arable land and abundant uranium deposits, which motivates the Chinese investors to invest here. China has pledged to improve the quality of education in the country. In 2012, it started to build two schools in Niamey.

In Congo, China erected several buildings, such as the radio and TV tower, Ministry of Foreign Affairs building, a hydroelectric power station, hospitals and roads. In exchange for these projects Congo pays with timber and oil. The outcome of this business deal is vast deforestation. While in 2011 the Chinese company Wang Sam Resources extracted 13 thousand cubic meters of wood in Congo, its plans for 2015 include 10 times more (AFP, 2012). Timber and oil are the main Chinese import articles from Congo. Congo also belongs to the bottom of the Doing Business 2011 listand has a weak rule of law (World Bank, 2011). Thus the determinants of Chinese investments in Congo clearly remain the natural resources.

China signed an investment agreement with the Guinean government in 2009 relating to mining in all the key mines of the country. Guinea extracts gold, diamonds and it is the biggest producer of bauxite in the world. Half of the word's bauxite deposits are located here. Guinea does not stand out from the African average neither with its GDP, area of arable land, trade volume with China, nor with its investment and political climate. The determinants of Chinese investments in this country are obviously natural resources.

In 2008, the construction of international airport in Luanda started. Subsequently, Linhas Aéreas de Angola started increasing the weekly number of flights to China. The Chinese company Pan-China Construction Ltd. participated in the construction of an Angolan green field town - Dundo. In 2009, the construction of two industrial parks began in the Bengo province, where China wants to build 115 factories. Since 2009 a Chinese car factory has been opened in Luanda. Acquiring a share in Marathon Oil Corp. as well as creating a joint venture with the company resulted in a growth in Chinese ODI a year later. In the case of 
Angola, GDP, natural resources and Chinese exports are statistically correlated with the growth of Chinese ODI flows. The area of its arable land also belongs to determinants of Chinese ODI.

The gradual worsening of the relations between Roberto Mugabe and the West has led to substantial improvements in the relations between the PRC and Zimbabwe. The Look East Policy has resulted in signing of several investment projects after the 2009 FOCAC summit in Sharm-el-Sheikh. China has invested in the reconstruction of the football stadium in Harare before the South African. It has also built infrastructure as well as developed the agricultural and mining sector. Zimbabwe possesses vast platinum ( $2^{\text {nd }}$ biggest to South Africa), chromite, gold and diamonds deposits in Chiadzwe. The main longstanding export article to China is tobacco and cotton. From natural resources it exports mainly iron ore, copper and nickel. Besides natural resources, the country has agricultural products to offer to the Chinese. China is currently the only foreign investor in Zimbabwe after the last German investors pulled out in 2010.

In countries where Chinese investments are less extensive, they are often present in the form of construction or reconstruction of government buildings, e.g. in 2008 in Guinea Bissau and Malawi. The reason for low investment interest from the Chinese side in some African countries is their diplomatic recognition of Taiwan. Although, there are currently four countries in Africa recognizing Taiwan instead of the PRC (Burkina Faso, Sao Tome, The Gambia and Swaziland), China has not completely cut off the trade relations with these countries. Comparatively small volumes of investments also currently flow to Tunisia and Libya despite of their significant natural resource deposits. The reason is the unrests in these countries, which have discouraged not only the Chinese but also other investors. After the unrests are over, the ODI in these countries is expected to grow substantially. The Chinese investors have shown interest in the construction of a luxurious tourist resort and an industrial park for electronics production aimed for the European market.

The area of arable land is statistically proven to be a determinant of Chinese investments in Africa (Szikorova, N., 2011, p. 1064-1075). It is also one of the current trends of the Chinese ODI. China currently imports agricultural produce from 40 African countries. With many countries China has signed agreements on agricultural cooperation beneficial for both parties involved. Examples are investments in planting jatropha trees for production of biofuels in Zambia, planting rice in Mozambique and Sierra Leone, investments in the agricultural development of Angola and Sudan, construction of an agricultural technology centre in Togo and Mozambique. China, at least for now, does not import produce of any of the agricultural plants it has invested in. They serve the domestic consumption and ensure food security and poverty reduction in Africa. However, in the long run it can be expected that after reaching a certain level in the development of agriculture in these countries, the excess production will find its way to China as 
well. The reasons for investing in African agriculture are plentiful; variability of agricultural production due to different climate in Africa as well as food security of Africa. On the other hand, there is a lack of arable land in China (only $12 \%$ of its total area), aggravated by environmental problems such as growing desertification, environmental degradation and urbanization, excessive utilization of pesticides and fertilisers to expand the agricultural production resulting in serious environmental issues, migration of Chinese farmers to the cities and loss of interest in jobs in this sector, excessive water pollution, excessive water exploitation due to which the northern provinces of China are affected by droughts. Not mentioning the fact that the labour productivity of the agricultural sector compared to other sectors of Chinese economy is very low- it generates only $10 \%$ of China's GDP, whereas it employs $35 \%$ of the total labour force (National Bureau of Statistics of China, 2009). Besides that the population is continuously growing, so does its demand for agricultural products, whereas China is already the biggest consumer of agricultural products in the world. The food security concerns that appeared after the agricultural product price shocks in 2007-2008 and the steadily growing prices of agricultural products increase the profits of farmers and land owners and raise the attractiveness of the sector. The rising demand for agriculture also increases the utilization of biofuels and technical crops

Considerable growth of the Chinese investments can be expected in countries with large areas of arable land: Nigeria, Sudan, Niger, South Africa and Ethiopia. The Chinese have also expressed interest in investing in Mozambique's wood processing industry, solar energy production and building industry. The investments will also increase in Botswana, where China pledged to finance the expansion of their power plant. By 2018 China plans to finish the construction of the Suez economic and trade cooperation zone in Egypt.

Natural resources will further remain one of the determinants of Chinese ODI in Africa. Almost every African country owns various natural resource deposits. Strategic resources will be in the limelight of the future investors, namely uranium, phosphates and critical minerals. On the basis of this analysis a list of the expected future biggest recipients of Chinese ODI in Africa can be created .

A new trend of African rivalry for China's attention can be expected too. A thorough analysis of the development of its investments in African economies reveals the fact that the newcomer countries received them principally for infrastructure, governmental buildings, sport stadiums, telecommunication services and recently also for agricultural development. Acquisition and establishment of subsidiaries in the banking sector, as well as the upsurge of loans for telecommunication service providers can be expected as well.

African leaders are in general satisfied with the Chinese influx of FDI and incite them to continue. The first signs of African desire to focus Chinese FDI more into industry have emerged, for example in COMESA. In order to achieve this ambition, the labour force needs to be retrained in many African countries. 
The Chinese government has promoted studies of African scholars in China; it also builds schools in Africa and sends its teaching staff to educate African students in order to meet the Chinese work requirements. The $12^{\text {th }}$ Five Year Plan presents the targets of the Chinese government for the period of 2011-2015 (Chinese government 2011). The seven strategic industries to be promoted in the coming years are: biotechnologies, new energy, high-end equipment manufacturing, energy conservation and environmental protection, clean-energy vehicles, new materials, and next-generation IT. Until 2015 they are expected to create $8 \%$ of China's GDP. Therefore, production relying on cheap labour force might be transferred to other developing countries, including Africa. China intends to support not only the development and the increase of competitiveness of African economies, but also the wages and living standards of both parties involved. A positive externality of this process will be the strengthening of friendly relations between the PRC and the African economies.

\section{Conclusion}

This paper presents an analysis of Chinese outward direct investments in Africa and projection of future investment flows. The motives that have led to a noticeable increase of these investments in Africa in the last 3 years were both based on the expansion to new markets and on cost minimization. The determinants associated with these motives in Africa are both primary commodity import, size of arable land, GDP, rule of law and trade relations.

The predominant factors behind the growing interest in these African countries are natural resources. However, they are not the sole determinant of Chinese ODI. China is further interested in investing in countries with vast areas of arable land and in countries with which it has extensive trade relations. Based on these determinants, the future trends in Chinese ODI in Africa are: an increase of investments in the agriculture, telecommunication and banking sectors, critical mineral mining and infrastructure.

\section{References}

ADB. (2010). African Statistical Yearbook 2010. URL: <http://www.afdb.org/fileadmin/uploads/ afdb/Documents/Publications/ADB_Yearbook_2010_web.pdf $>$ [accessed 16 March 2011].

AFP. (2011). Chinese firm to invest 10 million Euros in Congo forest area. Terradaily. URL: <http:// www.terradaily.com/reports/Chinese_firm_to_invest_10_million_euros_in_Congo_forest_ area_999.html $>$ [accessed 16 March 2011].

FAO. (2011). FaoStat - ResourceStat. URL: <http://faostat.fao.org/site/377/default.aspx\#ancor> [accessed 16 March 2011].

MOFCOM. (2011). 2010 Statistical Bulletin of China's Outward Foreign Direct Investment). Beijing: September 16. 
National Bureau of Statistics of China. (2009). China Statistical Yearbook 2009. Beijing: China Statistics Press, 2009.

Szikorova, N. (2011). Determinanty čínskych investícií v Afrike. Medzinárodnévzt'ahy2011: aktuálneotázkysvetovejekonomiky a politiky. EKONÓM: 1064-1075.

Szikorova, N. (2012).Súvislost'čínskychpriamychinvestícií a nerastnéhobohatstva v autokratickýchrežimovAfriky.Medzinárodnévzt’ahy: vedeckýčasopis pre medzinárodnépolitické, ekonomické, kultúrne a právnevzt’ahy. (10), (1): 36-44.

UNCTAD. (2011). Handbook of Statistics 2010.New York: United Nations Publication.

UNDP. (2011). Human Development Report 2011. New York: Palgrave Macmillan.

World Bank. (2011). Doing Business 2012. Washington: The World Bank.

World Bank. (2011). World Development Indicators. New York: World Bank Publications.

World Bank. (2011). World Governance Indicators. URL: <http://info.worldbank.org/governance/ wgi/index.asp> [accessed 16 March 2011]. 